\title{
High-cycles Fatigue of Different Casted Secondary Aluminium Alloy
}

Lenka Kuchariková, Eva Tillová, Milan Uhríčik, Juraj Belan, Ivana Švecová

Faculty of Mechanical Engineering, University of Žilina. Univerzitná 8215/1, 01026 Žilina. Slovak Republic. E-mail: lenka.kucharikova@fstroj.uniza.sk, eva.tillova@fstroj.uniza.sk, milan.uhricik@fstroj.uniza.sk, juraj.belan@fstroj.uniza.sk, ivana.svecova@fstroj.uniza.sk

\begin{abstract}
Nowadays manufacturers currently use about $35 \%$ of secondary aluminium and about $65 \%$ of primary aluminium to meet their needs. The production of secondary Al alloys have significant advantages. Most important is saving of natural resources with a consequent material cost reduction and a considerable energy-saving associated to reduction in pollution and $\mathrm{CO}_{2}$ emissions. The positive fact is that secondary $\mathrm{Al}$ alloys has comparable mechanical properties with primary aluminium alloys. Therefore it is necessary to study properties such alloys especially those which are used for transport industry in order to keeping the quality of casting. One of the major properties of casting for transport industry are fatigue properties. Research point to the fact that more than $90 \%$ of broken engineering components are fractures caused by fatigue of used material. Extremely dangerous are fatigue fractures in transport, for example rails, tire parts, plane wings and hulls of ships, because these are usually connected with human casualties. Due to this fact were studied fatigue properties of aluminium alloys used especially for automotive castings - AISi9Cu3. The great object was influence of casting to the different mould (sand and metallic) without modification, heat treatments or grain refinement of experimental material to fatigue resistance of the casting. This work shows differences between materials properties which were casted into the different mould.
\end{abstract}

Keywords: Fatigue properties, aluminium castings, AlSi9Cu3 cast alloy, casting into the sand mould, casting into the metallic mould

\section{Acknowledgement}

This work has been supported by The Scientific Grant Agency of the Ministry of Education of the Slovak Republic $N^{o}$ 1/0533/15, No 044ŽU - 4/2017 and EU project ITMS 26220220154.

\section{References}

[1] KAROLCZUK, A., KUREK, M., ŁAGODA, T. (2015). Fatigue life of aluminium alloy 6082 T6 under constant and variable amplitude bending with torsion. In: Journal of theoretical and applied mechanics, Vol. 53, No. 2, pp. 421-430, Warsaw, DOI: 10.15632/jtam-pl.53.2.421.

[2] SHAHA, S.K. et al. (2015). Improving high-temperature tensile and low-cycle fatigue behavior of Al-Si-Cu-Mg alloys through micro-additions of Ti, V, and Zr. In: Metallurgical and Materials Transactions A: Physical Metallurgy and Materials Science. Vol. 46, No. 7, pp. 3063-3078.

[3] ROMANKIEWICZ, R., ROMANKIEWICZ, F. (2014). The influence of modification for structure and impact resistance of silumin AlSi11. In: Production Engineering Archives, Vol. 3, No. 2, pp. 6-9.

[4] LI, Z. et al. (2017). Influence of Sr, Fe and Mn content and casting process on the microstructures and mechanical properties of AlSi7Cu3 alloy. In: Materials Science and Engineering A. Vol. 689, pp. 286-297.

[5] FINKELSTEIN, A. (2017). Microstructures, mechanical properties ingot AlSi7Fe1 after blowing oxygen through melt. In: Acta Metallurgica Slovaca. Vol. 23, No. 1, pp. 4-11.

[6] BONOLLO, F., URBAN, J., BONATTO, B., BOTTER, M. (2005). Gravity and low pressure die casting of aluminium alloys. In: A technical and economical benchmark la metallurgia italiana Vol. 6, pp. 23 -32.

[7] SHAHA, S.K. et al. (2017). Ageing characteristics and high-temperature tensile properties of Al-Si-Cu-Mg alloys with micro-additions of Mo and Mn. In: Materials Science and Engineering A. Vol. 684, pp. 726-736.

[8] SHAHA, S. (2016). Effect of Mn and heat treatment on improvements in static strength and low-cycle fatigue life of an Al-Si-Cu-Mg alloy. In: Materials Science and Engineering A. Vol. 657, pp. 441-452.

[9] Aluminium Casting Techniques - Sand Casting and Die Casting Processes. Available on-line https://www.azom.com/article.aspx?ArticleID=1392 May, 2002.

[10] Gravity die vesting. Available on-line: https://www.mrt-castings.co.uk/Gravity_Die_Casting.html.

[11] REDDY, C., RAJANNA, Ch. (2009). Design of gravity die casting process parameters of Al-Si-Mg alloys. A. In: Journal of Machining and Forming Technologies, Vol. 1, No. 1/2, pp. 1 - 25. 
[12] BOKU゚VKA, O., NICOLETTO, G., KUNZ, L., PALČEK, P., CHALUPOVÁ, M. (2002). Low and High Frequency fatigue testing. EDIS ŽU in Žilina.

[13] ULEWICZ, R., MAZUR, M. (2013). Fatigue testing structural steel as a factor of safety of technical facilities maintenance. In: Production Engineering Archives, Vol. 1, No. 1, pp. 32-34.

[14] BOKU゚VKA, O., JAMBOR, M., NOVÝ, F., TRŠKO, L., LAGO, J. (2016). Influence of long-term heating on the fatigue properties of low-alloyed cast steel STN 42 2707. In: Production Engineering Archives, Vol. 12, No. 3, pp. 30-33.

[15] TRŠKO, L., BOKŮVKA, O., NOVÝ, F., LAGO, J. (2016). Quality and fatigue characteristics relation. In: Production Engineering Archives, Vol. 10, No. 1, pp. 9-12.

[16] NOVÝ, F. et al. (2016). Fatigue Durability of Ductile Iron in very-high-cycle region. In: Manufacturing technology, Vol. 16, No. 2, pp.406-409.

[17] TRŠKO, L. et al. (2013). Dynamic strength and fatigue lifetime. EDIS ŽU in Žilina.

[18] BOYER, H.E., (1986). Atlas of fatigue curves. Fatigue testing. Available on-line: http://www.asminternational.org/documents/10192/1849770/06156G_Sample.pdf/6202c5f3-9ae8-479b-a8bd-d2050d37d534

[19] LAGO, J., GUAGLIANO, M., NOVÝ, F., BOKU゚VKA, O. (2016). Influence of laser shock peening surface treatment on fatigue endurance of welded joints from S355 structurl steel. In: Manufacturing technology. Vol.16, No.1, pp. 154-159.

[20] BOKU゚VKA, O., NOVÝ, F., GUAGLIANO, M., MIKOVÁ, K. (2011). High cycle and ultra-high cycle fatigue of corrosion resistant steel AISI 316L and AISI 316Ti. (Vysokocyklová a ultravysokocyklová únava koróziivzdorných ocelí AISI 316L a AISI 316Ti). In: Chemical letters (Chemické Listy), Vol. 105, pp. 624-626 (In slovak).

[21] KUCHARIKOVÁ, L. TILlOVÁ, E., BELAN, J. ZÁVODSKÁ, D., ŠVECOVÁ, I. (2016). The porosity evaluation with using image analyser software in aluminium cast alloys. In: Manufacturing technology, 2016, Vol. 16, No. 5, pp. 989-994.

[22] KUCHARIKOVÁ, L. TILlOVÁ, E., BELAN, J. VAŠKO, A., ŠVECOVÁ, I. (2017). Quantitative assessment of aluminium cast alloys`structural parameters to optimize its properties. In: Metalurgija, Vol. 56, No. 1-2, pp. 145148.

[23] BOKU゚VKA, O., NICOLETTO, G., GUAGLIANO, M., KUNZ, L., PALČEK, P., NOVÝ, F., CHALUPOVÁ, M. (2014). Fatigue of Materials at low and high frequency loading, EDIS 2014, first edition, pp. 146, ISBN 978-80554-0857-6

[24] ULEWICZ, R., NOVÝ, F. (2017). Fatigue lige of high strength steel for cold forming. In: Meralurgija, Vol. 56, No.(1-2), pp. 115-118. 